\title{
Recent Advances on the Use of Natural and Safe Alternative Method to Control Grey Mould of Grapes
}

\author{
Mahendra Dahiwale ${ }^{1, *}$, N S Suryawanshi ${ }^{2}$ \\ ${ }^{1}$ Department of Botany, K. M. Agrawal College of Arts, Commerce and Science, Kalyan 421301, Dist.-Thane, Maharashtra, India \\ ${ }^{2}$ Department of Botany, K V Pendharkar College of Arts, Science and Commerce, Dombivali, India
}

Received March 20, 2021; Revised May 12, 2021; Accepted June 6, 2021

\begin{abstract}
Cite This Paper in the following Citation Styles
(a): [1] Mahendra Dahiwale, N S Suryawanshi, "Recent Advances on the Use of Natural and Safe Alternative Method to Control Grey Mould of Grapes," Advances in Zoology and Botany, Vol. 9, No. 4, pp. 77 - 82, 2021. DOI: 10.13189/azb.2021.090401.
\end{abstract}

(b): Mahendra Dahiwale, N S Suryawanshi (2021). Recent Advances on the Use of Natural and Safe Alternative Method to Control Grey Mould of Grapes. Advances in Zoology and Botany, 9(4), 77 - 82. DOI: 10.13189/azb.2021.090401.

Copyright@2021 by authors, all rights reserved. Authors agree that this article remains permanently open access under the terms of the Creative Commons Attribution License 4.0 International License

\begin{abstract}
Grey mould of grapes (Vitis vinifera L var. red globe) caused by Botrytis cinerea Pers. ex. Fr. is recorded as an economically serious pathogen found in stored and imported grapes in India and which may cause heavy loss in all grape producing countries. Therefore the management of grey mould is equally important. In conventional agriculture the application of fungicides to grapes after harvest to reduce decay has been increasingly, curtailed by the development of pathogen resistance, the lack of knowledge of fungicide, negative public approach regarding the safety of pesticides and consequent restrictions on fungicide use. The study of alternative methods to control of grey mould decay has developed over several decades. Twenty five isolates of B.cinerea were isolated from infected samples of grape collected from various localities of Maharashtra. Out of which isolate $B c-19$ was highly sensitive $(290.8 \mu \mathrm{g} / \mathrm{ml})$ while isolate $B c$ - 11 was resistant $(1095.1 \mu \mathrm{g} / \mathrm{ml})$. Sensitivity of $B$. cinerea was tested using thiophanate methyl by food poisoning methods. Experiments were performed in Research Laboratory, KVP to find out the natural and safe alternative method to control of resistant $B c-11$. Six fungicides viz. dithane M-45, thiram, zineb, benomyl, carbendazim and captafol were used individually and in mixture with thiophanate methyl. Benomyl gave a significant PCE individual at $50 \mu \mathrm{g} / \mathrm{ml}(70.01)$ and at 100 $\mu \mathrm{g} / \mathrm{ml}$ PCE value (83.12) when compared with thiophanate methyl at $100 \mu \mathrm{g} / \mathrm{ml}$ (58.12), Captafal $50 \mu \mathrm{g} / \mathrm{ml}$ and 100 $\mu \mathrm{g} / \mathrm{ml}$ (64.18), zineb $50 \mu \mathrm{g} / \mathrm{ml}(62.13)$ and $100 \mu \mathrm{g} / \mathrm{ml}$ (75.15) PCE values, thiram at $50 \mu \mathrm{g} / \mathrm{ml}(54.12)$ and 100
\end{abstract}

$\mu \mathrm{g} / \mathrm{ml}$ (PCE- 65.10) and dithane M-45 at $50 \mu \mathrm{g} / \mathrm{ml}$ PCE (38.02) and $100 \mu \mathrm{g} / \mathrm{ml}$ (48.15) PCE values. Dithane and thiram was less effective. Trichoderma viride was found to be the most effective in reducing the colony diameter of $B$. cinerea $(69.89-68.12)$. Thus $T$. viride proves better and safe for the management of $B$. cinerea of grape as a biocontrol agent.

Keywords Grey Mould, Grapes, Botrytis cinerea, Thiophanate Methyl, Trichoderma, Antagonism

\section{Introduction}

The most postharvest decay of table grapes (Vitis vinifera $\mathrm{L}$ var. red globe) caused by Botrytis cinerea Pers ex.Fr. is recorded as an economically serious pathogen found in stored and imported grapes in India and which may cause heavy loss in all grape producing countries. It is an apportunistic pathogen on a wide variety of crops, causing a disease known as grey mould through infections via wound [11]. The world wide post harvest loss is great and immense due to $B$. cinerea ranged between 10 to $50 \%$.The use of chemical becomes essential when use of resistant varieties, fungal cultural practices or alternation of the environment is inadiequate to manage this pathogen. Nowdays, chemicals play role in crop protection $[9,10]$. In cold stored grapes $\left(-1^{\circ} \mathrm{C}\right)$, the main decay pathogens are B.cinerea Pers., Cladosporium herbarum Link., Alternaria alternata Keissler, Rhizopus stolonifer Ehrenb, 
Aspergillus niger Bainer and Penicillium expansum Link. Further losses occur during grading, packing, transport and finally marketing as fresh produce. Among these pathogens B.cinerea Pers. is most trouble because of its vigrous growth rate and ability to spread among grapes $[7,8]$. However, the use of systemic fungicides are not allowed on grapes and there are incresing regulatory restrictions on the use of chemical fugicides.

The use of alternative method to control postharvest decay of table grape extensively reviewed. Therefore minimize the economic losses and improve the quality of grapes. To develop management strategies to reduce fungicide used and adopt natural and safe alternative method to control the grey mould of grape. Wherein biological control would be significant [3]. Trichoderma is known to play an important role in natural and safe alternative because of it is easy to isolate and culture, grow rapidly on many medium and affect of a wide range of plant pathogen $[1,2,4]$.

Present investigation was carried out to evaluate a number of Trichoderma species and isolate, alone and in combination with different fungicides viz. benomyl, dithane, zeneb, thiram and captafol for the controlling B.cinerea.

\section{Materials and Methods}

\subsection{Isolation of Botrytis cinerea}

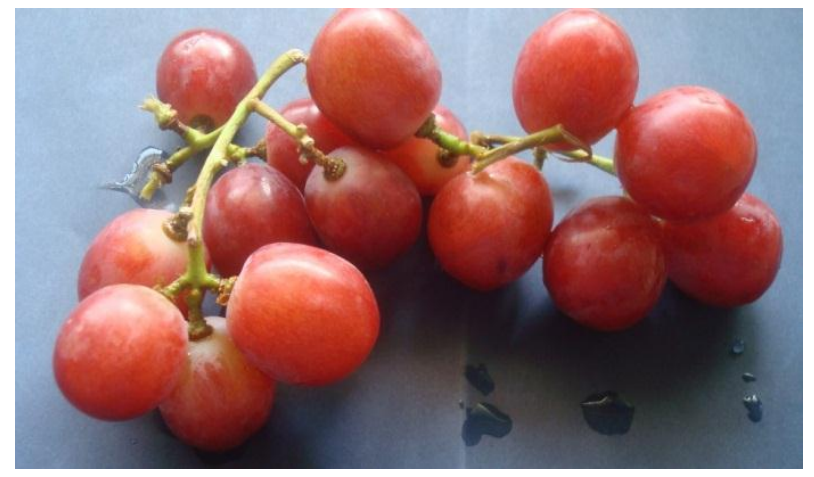

Figure 1a. Healthy Fruit of Grape

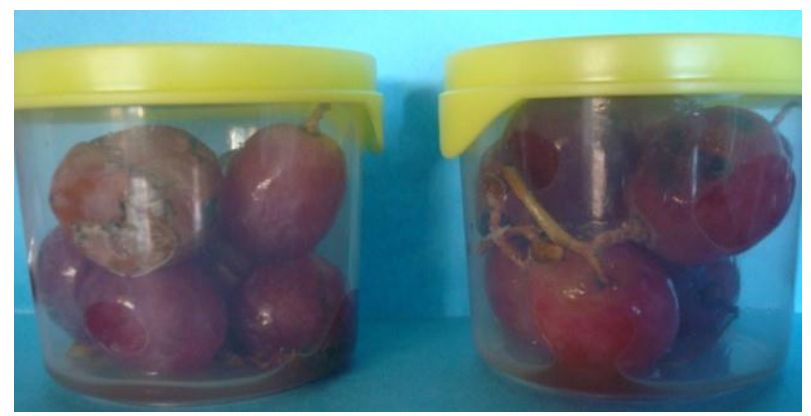

Figure 1b. Infected Fruit of Grapes
Infected samples were collected from different localities of Maharashtra in 2008 to 2011. The infected samples were surface sterilized with $0.1 \% \mathrm{HgCl}_{2}$ solutions for one minutes with gentle agitation. Samples were rinsed with sterile distilled water (SDW) up to 5 to 6 times then cut into smaller pieces and place aseptically at equidistant onto sterile potato dextrose agar (PDA) augmented with streptomycin $(20 \mu \mathrm{g} / \mathrm{ml})$ in petriplates. Plates were incubated at $22 \pm 2^{\circ} \mathrm{C}$ in dark for seven days. The pure culture of the pathogen was obtained. The pathogen was purified using PDA medium. Seven days old culture of $B$. cinerea were used for the experiement. Sensitivity of $B$. cinerea was tested using thiophanate methyl by food poisoning methods [6]. Isolate $B c-11$ was resistant while isolate $B c-19$ are sensitive were obtained. Resistant $B c-11$ was used for the experiement (Table 2).

\subsection{Isolation of Trichoderma spp.}

Three isolates of Trichoderma were isolated from mangrove soil of Thane creek. Approximately 20 gms of soil were added to $100 \mathrm{ml}$ of SDW and shaking well for $15 \mathrm{~min}$. The resultant suspension used to inoculate in PDA. All plates were incubated at room temperature $22 \pm 2^{\circ} \mathrm{C}$. The fungal colonies appearing after 7 days were picked and restreaked until pure culture were obtained. The fungal colonies were identified and used against B.cinerea. PDA broth pour in $250 \mathrm{ml}$ conical flask and inoculate the T.viride. and T.harzianum and inoculate at $22 \pm 2^{\circ} \mathrm{C}$. After seven days T.viride. and T.harzianum were separated from the broth mycelial mats were used. Dried mycelial mat were grinded in powder form. Powder of Trichoderma and fungicides were used against B.cinerea in vitro.

\section{Results and Discussions}

Table 1 and fig 2 revealed that twenty-five isolates of $B$. cinerea were isolated from infected samples of grape using PDA. The table 2 showed that sensitivity of B.cinerea isolates to thiophanate methyl were tested. The thiophanate methyl sensitivity was determined by measuring the linear growth of B.cinerea colony on agar plate after eight days of inoculation. Plates without thiophanate methyl serve as control. Each treatment was replicated three times. There are quite variations in MIC of thiophanate methyl against grey mould pathogen. MIC ranged from 530 to $1280 \mu \mathrm{g} / \mathrm{ml}$. The isolate $B c-19$ was sensitive and $B c-11$ was resistant. It is revealed that powder of Trichoderma and fungicides were used against B.cinerea in vitro. T. viride was found overgrew of B.cinerea therefore in proved that $T$. viride shows strong antagonistic properties (Fig 3). 
Table 1. In vitro sensitivity of thiophanate methyl against Botrytis cinerea

\begin{tabular}{|c|c|c|}
\hline Isolates & $\mathrm{ED}_{50}(\mu \mathrm{g} / \mathrm{ml})$ & $\operatorname{MIC}(\mu \mathrm{g} / \mathrm{ml})$ \\
\hline$B c-1$ & 380.2 & 980.2 \\
\hline$B c-2$ & 140.1 & 349.3 \\
\hline$B c-3$ & 250.4 & 590.1 \\
\hline$B c-4$ & 390.3 & 600.5 \\
\hline$B c-5$ & 193.0 & 585.9 \\
\hline$B c-6$ & 280.4 & 591.7 \\
\hline$B c-7$ & 265.8 & 615.4 \\
\hline$B c-8$ & 400.4 & 475.6 \\
\hline$B c-9$ & 280.9 & 585.7 \\
\hline$B c-10$ & 470.2 & 995.6 \\
\hline$B c-11$ & 510.7 & 1095.1 \\
\hline$B c-12$ & 360.5 & 594.2 \\
\hline$B c-13$ & 310.6 & 695.3 \\
\hline$B c-14$ & 195.7 & 312.5 \\
\hline$B c-15$ & 210.4 & 600.5 \\
\hline$B c-16$ & 300.8 & 635.3 \\
\hline$B c-17$ & 270.3 & 615.1 \\
\hline$B c-18$ & 295.7 & 780.1 \\
\hline$B c-19$ & 130.2 & 290.8 \\
\hline$B c-20$ & 330.4 & 627.1 \\
\hline$B c-21$ & 400.3 & 885.9 \\
\hline$B c-22$ & 310.7 & 625.4 \\
\hline$B c-23$ & 290.9 & 631.3 \\
\hline$B c-24$ & 420.3 & 905.2 \\
\hline$B c-25$ & 345.1 & 680.3 \\
\hline
\end{tabular}

$\mathrm{ED}_{50}$. Fungicide concentration causing $50 \%$ reduction in radial growth MIC - Minimal inhibitory concentration

Table 2. Sensitive and resistant isolate of Botrytis cinerea

\begin{tabular}{ccc}
\hline Isolate & $\mathrm{ED}_{50}(\mu \mathrm{g} / \mathrm{ml})$ & $\mathrm{MIC}(\mu \mathrm{g} / \mathrm{ml})$ \\
\hline Sensitive $(B c-19)$ & 130.2 & 290.8 \\
Resistant $(B c-11)$ & 510.7 & 1095.1 \\
\hline
\end{tabular}

Six fungicides viz. dithane M-45, thiram, zineb, benomyl, carbendazim and captafol were used individually and in mixture with thiophanate methyl. The concentration was used at $50 \mu \mathrm{g} / \mathrm{ml}$ and $100 \mu \mathrm{g} / \mathrm{ml}$ in potato dextrose agar medium (PDA). After 6 days growth of B.cinerea was observed and percentage control efficacy (PCE) was measured (Table 3 ). The results in table 3 showed that benomyl gave a significant PCE individual at $50 \mu \mathrm{g} / \mathrm{ml}(70.01)$ and at $100 \mu \mathrm{g} / \mathrm{ml}$ PCE value (83.12) when compared with thiophanate methyl at $100 \mu \mathrm{g} / \mathrm{ml}$ (58.12). Carbendazim at $50 \mu \mathrm{g} / \mathrm{ml}(65.03)$ and $100 \mu \mathrm{g} / \mathrm{ml}$ PCE values increased upto 70.05 as compared with thiophanate methyl. Captafal $50 \mu \mathrm{g} / \mathrm{ml}$ and $100 \mu \mathrm{g} / \mathrm{ml}$ (64.18) and (66.33) respectively and fallowed by zineb (62.13), (75.15) PCE values. Thiram at $50 \mu \mathrm{g} / \mathrm{ml}$ (54.12) and $100 \mu \mathrm{g} / \mathrm{ml}$ (PCE- 65.10) and dithane M-45 at 50 $\mu \mathrm{g} / \mathrm{ml}$ PCE (38.02) and $100 \mu \mathrm{g} / \mathrm{ml}$ (48.15) when compared with thiophanate methyl PCE values. Dithane and thiram was less effective individually (Table 3).

Fungicides were mix with thiophanate methyl in PDA. Test fungus inoculated at the centre of petriplate, after 6-7 days colony diameter was measured and PCE value determined. PCE was highly increased with benomyl, carbendazim, captafol, zineb, thiram and dithane M-45. It was going upto $42.08-75.88$ at $50 \mu \mathrm{g} / \mathrm{ml}$ concentration while PCE values ranged from $60.10-86.12$ at $100 \mu \mathrm{g} / \mathrm{ml}$ concentration. Benomyl use as systemic fungicide PCE 75.88 as $50 \mu \mathrm{g} / \mathrm{ml}$ and 86.12 at $100 \mu \mathrm{g} / \mathrm{ml}$ as compared with individually and in mixture with thiophanate methyl PCE value appeared more fruitful and fallowed by other fungicides.

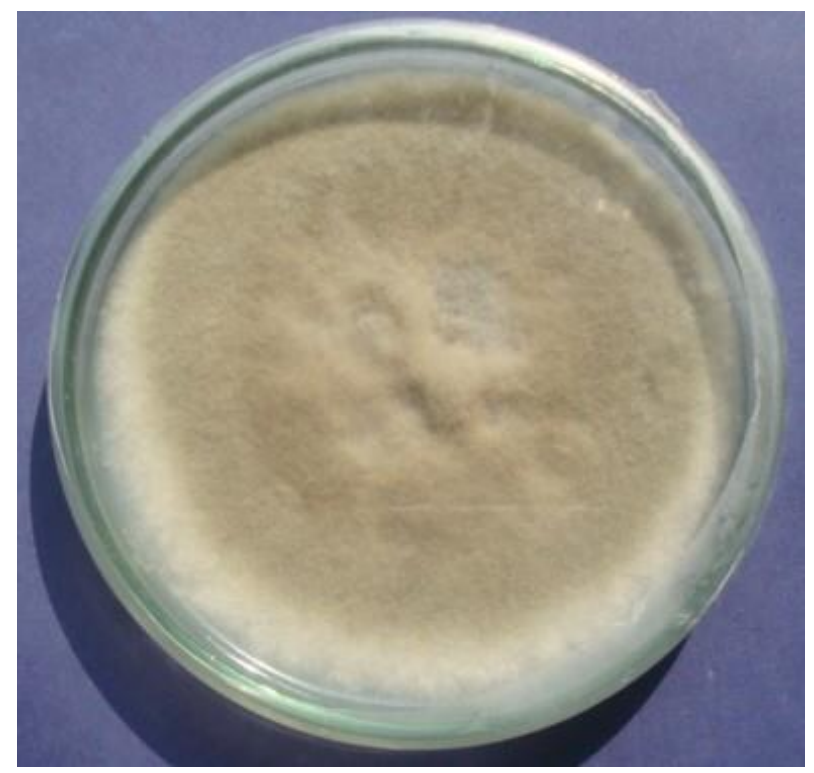

Figure 2. Pure culture of B.cinerea Pers.ex Fr. on PDA

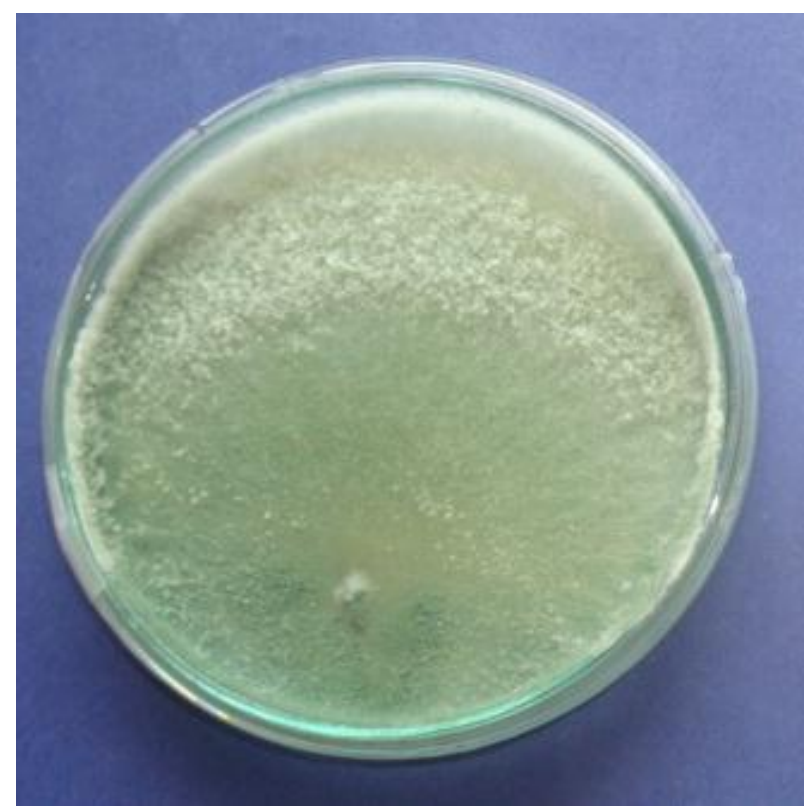

Figure 3. Trichoderma viridae overgrew on B.cinerea 
Table 3. PCE of thiophanate methyl individually and in mixture with other fungicide against resistant mutant (Bc-EMS-4) of B.cinerea Pers. ex. Fr on PDA plate.

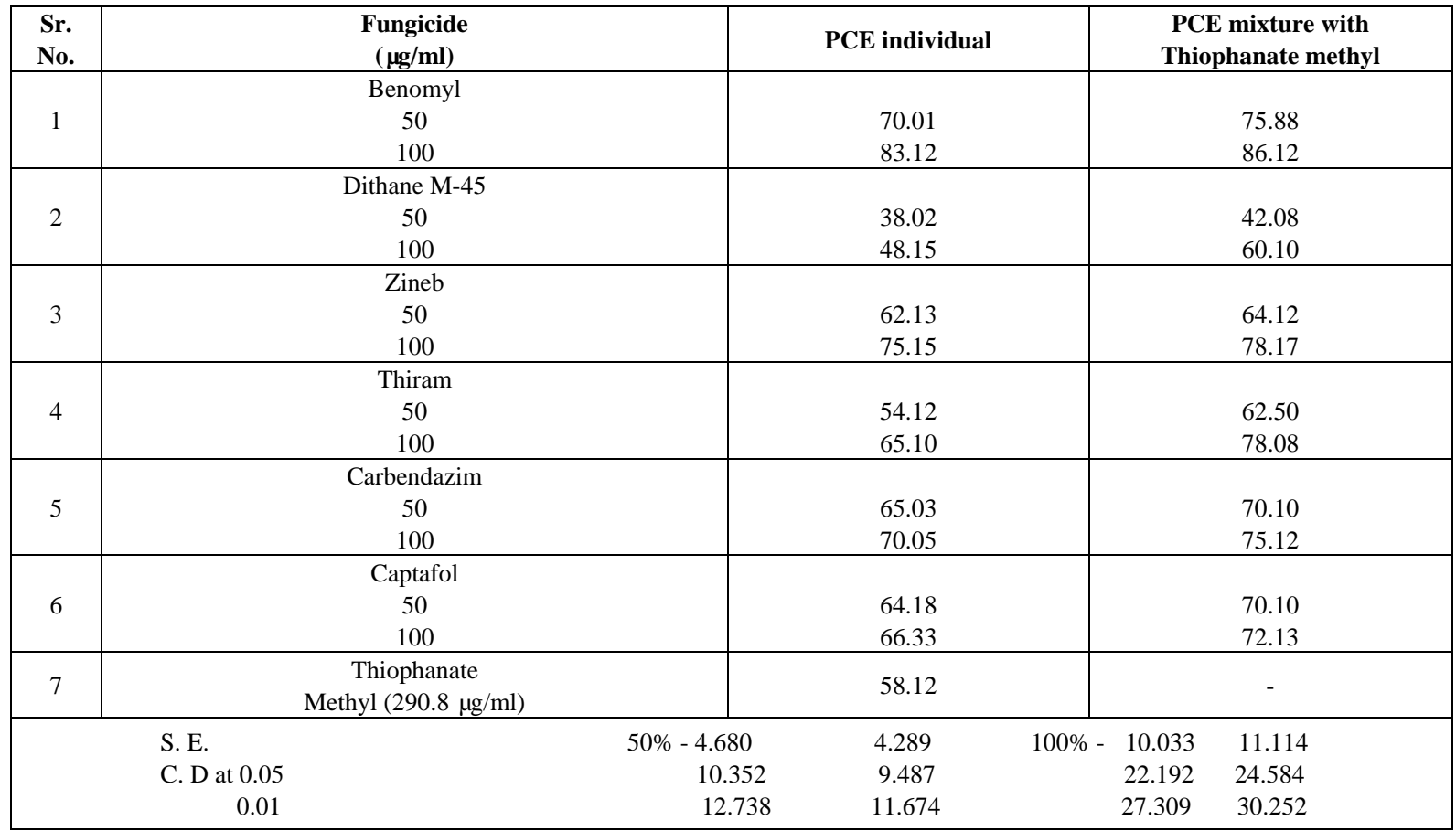

Values are the mean of three replicates.

Table 4 revealed that the effects of the three species of Trichoderma that had the greatest potential of antifungal activity. T. viride and T. harzianum was found to be the most effective in reducing the colony diameter of $B$. cinerea $(69.89-68.12)$. It also reported that $T$. viride and T. harzianum significantly suppressed Fusarium udam is soil and roots of pigeon pea [9]. Reference [8] observed that the isolate of $T$. virens and $T$. viride were the most effective in which maximum growth inhibition of mycelium of Fusarium oxysporium was recorded i.e., $77.7 \%$ and $77.55 \%$. Reference [5] reveals that Trichoderma emerged as most potential bioprotectants for management of wide variety of plant diseases. Table 5 revealed that all treatment significantly reduced the inhibition zone of B.cinerea. The treatment with powder of Trichoderma and fungicides (dithane M-45, carbendazim, thiophanate methyl, antracol and benomyl) gave overall steady results.

Table 4. Management of Botrytis cinerea using biocontrol agent

\begin{tabular}{|c|c|c|c|}
\hline Sr. No. & Fungicides & PCE & $\begin{array}{c}\text { PCE mixture } \\
\text { with thiophanate } \\
\text { methyl }\end{array}$ \\
\hline 1 & Trichoderma viride & 64.06 & 69.89 \\
\hline 2 & $\begin{array}{c}\text { Trichoderma } \\
\text { harzianum }\end{array}$ & 51.85 & 68.12 \\
\hline 3 & Trichoderma koeningi & 42.54 & 59.12 \\
\hline 4 & $\begin{array}{c}\text { Thiophanate methyl } \\
(290.8 \mu \mathrm{g} / \mathrm{ml})\end{array}$ & 64.74 & - \\
\hline
\end{tabular}

Means of Three replicates 
Table 5. Integrated management of Botrytis cinerea on CDA medium

\begin{tabular}{|c|c|c|c|}
\hline Sr.No. & Antagonist & Dose $(\boldsymbol{\mu g} / \mathbf{m l})$ & PCE \\
\hline 1 & Trichoderma viride + Benomyl & 100 & $51.21(4.2)$ \\
\hline 2 & Trichoderma viride + Dithane M-45 & 100 & $53.65(4.4)$ \\
\hline 3 & Trichoderma viride + Zeneb & 100 & $58.53(4.8)$ \\
\hline 4 & Trichoderma viride + Thiram & 100 & $50.00(4.1)$ \\
\hline 5 & Trichoderma viride + Carbendazim & 100 & $47.56(3.9)$ \\
\hline 6 & Trichoderma viride + Captafol & 100 & $40.12(3.1)$ \\
\hline 7 & Trichoderma harzianum + Dithane M-45 & 100 & $52.43(4.3)$ \\
\hline 8 & Trichoderma harzianum + Carbendazim & 100 & $54.87(4.5)$ \\
\hline 9 & Trichoderma harzianum+ Thiophanate methyl & 100 & $63.41(5.2)$ \\
\hline 10 & Trichoderma harzianum + Antracol & 100 & $51.21(4.2)$ \\
\hline 11 & Trichoderma harzianum + Benomyl & 100 & $48.78(4.0)$ \\
\hline 12 & Trichoderma harzianum + Captafol & 100 & $40.20(3.0)$ \\
\hline 13 & Trichoderma koningi + Dithane M-45 & 100 & $56.09(4.6)$ \\
\hline 14 & Trichoderma koningi +Carbendazim & 100 & $54.87(4.5)$ \\
\hline 15 & Trichoderma koningi + Thiophanate methyl & 100 & $65.85(5.4)$ \\
\hline 16 & Trichoderma koningi + Antracol & 100 & $41.46(3.4)$ \\
\hline 17 & Trichoderma koningi + Benomyl & 100 & $43.90(3.6)$ \\
\hline 18 & Trichoderma koningi + Captafol & & $38.12(3.1)$ \\
\hline 19 & Control & $(8.2)$ \\
\hline
\end{tabular}

Means of three replicates

\section{Conclusion}

1. Grape (Vitis vinifera L.) is an important fruit of India and its losses are much higher because operations to protect grapes from mechanical damage during storage. In storage condition various fungal pathogens destroyed the fruits. The grey mould is a very destroying pathogen on grapes therefore management is equally important.

2. A total of 25 isolates of $B$. cinerea were tested for their thiophanate methyl sensitivity by food poisoning method. There was quite a large variation in the sensitivity among the isolates collected from various places. In vitro isolate $B c-19$ was sensitive while isolate $B c$ - 11 was resistant. $B c$ - 11 resistant isolate was used further studies for the management.

3. Use of thiophanate methyl was found highly effective in controlling of grey mould caused by $B$. cinerea. Individually thiophanate methyl was more effective.

4. Trichoderma viride was highly effective PCE followed by $T$. harzianum, T. koningi.

5. Currently biological control is considered very promising alternatives to fungicide in control of post-harvest decay of grapes. Fungal antagonist $T$. viride and T. harzianum was found greatest inhibitory effect $(69.89 \%$ and $68.12 \%)$.

6. Biological agents viz. T. viride, T. harzianum and T. koningi are ecofriendly and considered best for management of grey mould disease caused by $B$. cinerea, reducing mycelia growth upto 83.52 percentage.

7. Integration approaches of biocontrol agent i.e., T. viride, T. harzianum with thiophanate methyl was beneficial in controlling of this disease but not more effective.

Research during the previous five decades indicates another potential option for fruit disease management. That is the biological control of fruit diseases. Bio-control assumes special significance in being an eco-friendly and cost-effective strategy that should be used in integration with other strategies for a greater level of protection with sustained fruit production.

\section{Acknowledgements}

We express thanks to Late Dr. L.V. Gangawane, Emeritus Professor, Plant Pathology Laboratory, Dr. Babasaheb Ambedkar Marathwada University, Aurangabad, for valuable suggestion and encouragement.

Authors are also express thanks to Principal, Teaching Staffs and Non-teaching staffs of the College for Laboratory facilities and support.

Last but not we thank all our research colleagues R.N. Baviskar, Tushar Rodge, Jaideep Patil and Jayshree Jagtap for great support 


\section{REFERENCES}

[1] El. Ghouth A. and C.L. Wilson. Biological based techniques for the control of postharvest diseases. Post-harvest News and information, 6:5-11, 1995.

[2] Harman G.E., Howell C.R., Viterbo A., Chet I., and M. Lorito. Trichoderma species- opportunistic avirulent plant symbioents. Nature rev. Microbiol. 2: 43-56, 2004.

[3] Leininger W., Breuker B., Hahn M. and Mendgen K. Control of postharvest pathogens and colonization of the apple surface by antagonistic microorganisms in the field. Phytopathology. 87: 1103-1110, 1997.

[4] Mukerji K.G. and Garg K.L. Biocontrol management of plant Diseases. II CRC Press Inc. Boca Raton, Florida, 1988.

[5] Mukhopadhyay A.N. Trichoderma for plant disease management a reality or myth. $64^{\text {th }}$ IPS meeting and National Symposium2-4 Dec.:2, 2011.

[6] Nene Y.L. and Thapliiyal P.N. Fungicides in Plant disease control. Oxford and IBH publishing Company. New Delhi, 2nd edition, 1982.

[7] S.P. Ghosh. Research preparedness for accelerated growth of horticulture in India. Journal of Applied Horticulture, 1(1): 64-69, 1999.

[8] Sharma Nidhi and P.C. Trivedi. Evaluation of different fungal antagonists, plant extracts and oil cakes against Fusarium oxysporum $f$. sp. cumini causing wilt of cumin (Cuminum cyminum L.). J. Ind.Bot. Soc. 84:30-32, 2005.

[9] Seiya Saito and Shunji Suzuki. Fungicide resistant profile and Botrytis cinerea in vineyard J. Asev J pn 20 (1-2):8-14, 2009.

[10] Tripathi Pramila, N.K. Dubey and A.K. Shukla Use of some essential oils as postharvest botanical fungicides in the management of grey mould of grapes caused by Botrytis cinerea. World J. Microbiol. Biotechnol 24:39-46, 2008.

[11] Williamson B., Tudzynski B., Tudzynski P and J.A.L. Van Kan. Botrytis cinerea the cause of grey mould disease. Mole. Plant. Pathol.8:561-580, 2007. 